Consumer vulnerability and the transformative potential of Internet shopping: An exploratory case study

Dr Jonathan Elms

Lecturer

Institute for Retail Studies

Stirling Management School

University of Stirling

Stirling

FK9 4LA

Telephone: 01786467375

Fax: 01786464745

Email: j.r.elms@stir.ac.uk

$\&$

Dr Julie Tinson

Senior Lecturer

Research Centre for Consumers, Cultures \& Society

Stirling Management School

University of Stirling

Stirling

FK9 4LA

Telephone: 01786467389

Fax: 01786464745

Email: j.s.tinson@stir.ac.uk 


\title{
Consumer vulnerability and the transformative potential of Internet shopping: An exploratory case study
}

\begin{abstract}
10 million individuals in the UK who suffer from long-term illness, impairments or disability can be considered as vulnerable consumers (Office for Disability Issues, 2010). Despite this, there are few studies on the use of the Internet for grocery shopping by the disabled and none which offers an understanding of the multiple facets of consumer vulnerability. The purpose of this study is to contextualise the use of the Internet for grocery shopping using an exploratory case to provide fresh insights into the 'actual' vulnerability of "Danni" - a disabled housewife and mother. The consumer focussed methods used here were combined multiple complementary approaches. The findings illustrate that whilst the use of the Internet reduces the impracticalities of shopping in-store, the normalcy afforded to Danni through shopping in-store (including her sense of self) was not met by the technological offerings. The paradoxes associated with using online provision and the strategies adopted to manage these by Danni demonstrate engagement/disengagement and assimilation/isolation. Policy implications and insights for retailers are provided.
\end{abstract}

\section{Keywords}

Consumer vulnerability, Transformative Consumer Research, Internet, Grocery Shopping, Ethnography

\section{Biographies}

Dr Jonathan Elms is a Lecturer in Marketing based in the Institute for Retail Studies, University of Stirling. He was previously a teaching fellow at Lancaster University Management School. Jonathan's research interests fall under the umbrella of consumer behaviour and retailing. More specifically, this includes retail change (particularly in relation to consumer choice and public policy debates), everyday consumption practices, and shopping spaces and places.

Dr Julie Tinson is a Senior Lecturer in Marketing at the University of Stirling where she principally teaches Consumer Behaviour and Marketing Communications. Her research interests include consumer socialisation and adolescent consumer behaviour in relation to transition. She has published widely on consumer behaviour in relation to families, adolescents and children and has recently written a book on researching with youth. 


\section{Introduction}

The concept of consumer vulnerability has recently gained increasing attention within the disciplinary fields of marketing and consumer behaviour (Hill \& Dickinson, 2005). The ensuing research has sought to untangle and polliticise the complexities of the phenomenon that can be understood as "a state of powerlessness that arises from an imbalance in marketplace interactions or from the consumption of marketing messages and products" (Baker et al., 2005, p. 134; Commuri \& Ekici, 2008).

Concurrently, there has been a growing acknowledgement that the changing geographies of corporate retail provision have critical implications for the life experiences of consumers (e.g. Miller et al., 1998; Whelan et al., 2002; Jackson et al., 2006). As such, innovations and developments in the retail sector, including Internet shopping, are likely to be perceived and experienced differently by individuals and particular social groups (Clarke et al., 2004). Indeed Internet shopping has often been mooted as a potential mechanism to address the socio-spatial constraints that have long been associated with consumers' access to stores (Templeman, 1999). It could therefore alleviate the experiences of vulnerability by those individuals who are excluded from fully participating in the physical marketplace (Social Exclusion Unit, 2005). This is a case in point for over 10 million individuals in the UK (approximately 1 in 6 of the total population) who suffer from long-term illness, impairments or disability (Office for Disability Issues, 2010).

To date, however, the use of the Internet by disabled persons for shopping purposes has received relatively scant attention in the extant literature. Notable exceptions are Childers and Kaufman-Scarborough's recent studies that have focused on the opportunities offered by Internet shopping for individuals with specific disabilities (Childers \& Kaufman- 
Scarborough, 2009; Kaufman-Scarborough \& Childers, 2009). Nevertheless, there has been a call for further, particularly qualitative, understandings of the online shopping motivations and needs of persons with disabilities. This is because the meanings attached to these types of behaviour are likely to manifest themselves in nuanced and idiosyncratic ways. Given that disability, as defined by the UK Equality Act 2010, encompasses a vast array of "physical or mental impairment which has a substantial and long-term adverse effect on [the individual's] ability to carry out normal day-to-day activities" this is not all that surprising.

Consequently, in this paper we aim to contribute to the emerging Transformative Consumer Research debate (see, Mick, 2008) by offering an exploratory understanding of how the multiple facets of consumer vulnerability and exclusion, as experienced by a disabled person, intersect and contextualise their use of the Internet for grocery shopping purposes. In doing so, we provide fresh and novel insights into the concept of consumer vulnerability that considers the temporal and transient dynamics of behavioural coping mechanisms as conceptualised by Mick and Fournier's (1998) in their "paradoxes of technology" framework.

Guided by the underlying principles of grounded theory (Glaser \& Strauss, 1967), this paper adopts an iterative approach that resonates between literature and data (see, Goulding, 2005). In the following section the concept of consumer vulnerability is introduced and its relevance reflected upon in relation to grocery shopping. Here, the inherent paradoxes of Internet shopping and its use by a disabled person are considered. Then the methodological approach utilised in the study is described and justified. The presentation of the empirical findings generated from a single, multi-method ethnographic case study into the store-based and Internet shopping practices of a disabled person - 'Danni', a wheelchair user (as a result of acute rheumatoid arthritis) and her husband, Rob, follows. Then conclusions that can be 
drawn from this research are discussed, the limitations of the study are considered, opportunities for future research are signalled, and a number of implications for public policy and retailers are presented.

\section{Understanding consumer vulnerability}

Consumer vulnerability is a complex phenomenon that can only be understood by listening to and observing the everyday encounters of the consumer in the marketplace (Baker et al, 2005). Theoretical understandings of consumer vulnerability have traditionally synonymised the concept with terms such as the "disadvantaged" or "neglected" consumer thereby focusing on how facets and structures such as low income, gender, race, illness, mobility and geography (Davies \& Champion, 1980; Westlake, 1993; Piachaud \& Webb, 1996) result in the exclusion of some consumers from participating with consumption-related activities relative to others. However, whilst broad social and economic inequalities and spatial circumstances lend themselves to instances of consumer vulnerability, it also manifests itself in socially constructed conventions and norms that can, in turn, serve to undermine consumers' ability to fully exercise their rights as citizens (Jordan, 1996; Williams \& Hubbard, 2001).

The concept of consumer vulnerability is considerably more rigorous than labels such as disadvantage and neglect, "as norms can (and do) change over time" (Baker et al, 2005, p. 134). The assertion being that, "disadvantage" appears to be more of a fixed state as opposed a fluid and transient or temporal one; and one that is not necessarily imposed. Therefore consumers who exhibit traits and characteristics of disadvantage and neglect may not be considered as being vulnerable all of the time (Baker, 2006). Indeed, Baker et al. (2005) in their seminal paper on understanding the domain of consumer vulnerability, emphasise that 
the concept is multidimensional and context specific (see also Hunter-Jones, 2011), and call for future research that attempts to explain "when populations studied are and are not vulnerable and when the context studied presents individuals with vulnerabilities" (p. 136).

\section{Grocery shopping: actual vulnerability versus unmet needs}

For many years, it has been recognised that grocery shopping is heavily dependent on geographic and location-based factors. It is also of note that considerable variations exist in the extent to which individuals and different consumer groups can access shopping outlets (Bromley \& Thomas, 1995). In part, this is somewhat inevitable as consumers tend to shop at stores that are in close proximity to their homes. Retailers also tend to cluster geographically in locations, where it is more economically viable to have a dense store network or choose instead to locate larger stores in areas that have higher residential densities (Guy, 2007). Whilst spatial variations exist in terms of consumer access to retail provisions, and, for some, physical distance may be considered as an overly time consuming activity or a chore, it is important to highlight that consumer vulnerability is not simply the same as dissatisfaction or an "unmet need" (Baker et al, 2005, p. 134). "Actual" vulnerability should be addressed as it is the misconception of what vulnerability really is that confuses our understanding of this concept.

Research focusing on the consumption practices of shoppers with visual impairments (e.g. Kaufman-Scarborough \& Childers, 2009) and wheelchair users (e.g. Milligan, 1998), indicate that experiences of vulnerability and social exclusion may, for example, arise from lack of access to shopping opportunities and that the logistical elements of the marketplace are not necessarily designed for people with physical disabilities (Baker \& Kaufman-Scarborough, 2001). Sociologists and cultural geographers have, for example, emphasised that disabled 
persons are often pushed out of the mainstream and are socialised to "know their place" (Kitchen, 1998, p. 347), and to accept poorer shopping opportunities through being taught patterns of self-shame, self-blame and self-doubt (Wendall, 1989). This is maintained and perpetuated by what Imrie (1996) describes as the place-inscribed dominant ideologies and practices of "abled-bodiness".

Furthermore, the organisation of space within stores can propagate and reproduce the position and status of disabled persons. Kitchen (1998) refers to this as "locking the disabled out". This can also be facilitated by the design and layout of stores, which often value aesthetics and form, designed as if all people are the same, or prioritising the abled-bodied (Matthews \& Vujakovic, 1995). This leads to certain parts of stores being perceived as "no go" (KaufmanScarborough, 1999) such as high shelves and insufficient width between aisles. Such are instances where retailers, and planners and architects of these spaces are guilty of what Imrie (1996) refers to as "design apartheid". It has also been recognised that even in such instances where space is designed for disabled access, it is often misused or obstacles are positioned so as to block its use and accessibility (Kaufman, 1995) either by employees of a store or by other shoppers who may be unaware of how such practices may exclude all but the majority of the population who reproduce able-bodiness as part of the everyday (Davis, 1995).

As Cahill and Eggleston (1995) illustrate, such exclusionary practices change the behaviour of some consumers who to attempt to avoid the crowd as well as not to "stand-out in the crowd" (Stiker \& Sayers, 1999, p. 3). Wheelchairs are often considered objects that reflect varying degrees of "social stigma" (Cahill \& Eggleston, 1995; Hebl, Tickle, \& Heatherton, 2000). Moreover, without actively challenging popularised cultural representations and the creation of myths which feed the malicious stereotypes of disabled persons as 
"hyperdependent, ignored or flawed" (Hevey, 1993, p. 424) consumers may experience vulnerability and isolation from the wider arena of consumption and consumer culture.

\section{Consumer vulnerability, identity and transformation}

Central to our understanding of consumer vulnerability is the notion, and interplay, between what Baker (2006) coins "normalcy", identity projects and transformation. Normalcy, or the perception of the "way things are supposed to be" (Baker, 2006, p. 39), enables the individual to enact and perform consumption practices that are central to the construction and affirmation of their sense of self. Accordingly shopping provides a platform for individuals to (re)negotiate and reinforce their consumer roles, identities and subjective positions within particular discursive and material contexts: "I am here. I am normal" (Baker, 2006, p. 42). Thus the practice of shopping enables consumers to be active agents in the formulation and construction of their identities as well as their position in the marketplace. Consequently "to be normal one has to be able to shop. Normal does not mean they have to shop. It means that they have to be able to shop" (Baker, 2006, p. 45).

Understood as a social and cultural phenomenon, shopping is considered as a skilful, complexly gendered, socially-embedded and situated practice (e.g. Jackson \& Holbrook, 1996; Miller, 1998). Despite speculation to the contrary, evidence would suggest that women still bear the brunt of the responsibility for grocery shopping and its related practices - such as meal organisation, preparation and cooking (Kan \& Gershuny, 2010). Indeed for many women, particularly mothers, their identities are inextricably interlinked with this repetitive and mundane act of provisioning (Miller, 1998). This reflects that the practice of grocery shopping is laden with moral and ethical undertones (Miller et al, 1998); whereby its successful performance enables women to enact their desired gendered roles and 
subjectivities as a "good" wife and/or mother (Valentine, 1999). Consequently in situations when a woman is unable to "shop properly" (Jackson et al, 2006) it is possible that this could serve to destabilise, or fail to "authenticate" (Arnould \& Price, 2000) her identity and prevailing social roles within the family (Moisio, Arnould, \& Price, 2004).

Shopping "properly" may hold particular parlance for disabled women (Hill \& Dhanda, 1999) whose access to the physical marketplace maybe difficult, if not impossible, without the assistance of other family members, or formalised care services. Therefore they are likely to experience a heightened sense of vulnerability (e.g. Kaufman-Scarborough, 2001). The extent of marketplace exclusion and experiences of vulnerability are, however, inevitably mediated by a disabled person's individual characteristics (for example, age, gender, class, political views, race/ethnicity, self-concept and personal appearance) and family/household circumstances (such as composition, size, stage in life-cycle, income and location of residence) as well as the nature and severity of their disability (see Baker et al, 2005).

Hand et al (2009) allude to Internet usage in a recent investigation into the situational influences on consumer behaviour that lead to the adoption of online grocery shopping. Their findings suggest that particular discontinuous events that occur in the everyday lives of consumers, such as the development of an illness or the birth of a child, are likely to "trigger" the use of the Internet for grocery shopping purposes. Nevertheless, grocery shopping is recognised as a routinised practice that is entrenched in habit (Jackson et al, 2006) and as a consequence these consumers still prefer to use this mode of shopping as a supplement rather than a stand alone replacement for shopping in-store. Consumers tend to discontinue their use of online grocery shopping once the initial trigger had disappeared. 


\section{The paradoxes of Internet shopping}

Much of the discourses surrounding information and communication technologies (ICTs) often regard the Internet (and related technologies) as a tangible way of "readdressing sociocultural disadvantage and marginalisation" (Lupton \& Seymour, 2000, p. 1852), and as such empowering and emancipating disabled persons with a means of transforming them into "competent normal subjects" (Amtmann \& Johnson, 1998). However an inherent paradox between disability and technology emerges. That is, the extensive use and engagement with the Internet, and thus, by default, a reliance on Internet shopping, by a disabled person reproduces the binaries of the "normal" and the "deviant" (Tiley, Bruce, \& Hallam, 2007) as well as the asymmetries that they seek to undo.

A useful framework for understanding the paradox of technologies and consumers' behavioural outcomes is offered by Mick and Fournier (1998). Unlike previous research that has tended to examine patterns of adoption of technologies and rates of diffusion by different individuals and social groups (e.g. Rogers, 1995), Mick and Fournier's study examined consumers' behaviour and attitudes towards and experiences of technology after it had been adopted. The eight paradoxes of technology isolated by these authors that consumers may experience in the post-adoption of Internet usage are illustrated in Table 1. These are: control/chaos, freedom/enslavement, new/obsolete, competence/incompetence, efficiency/inefficiency, fulfils/creates needs, assimilation/isolation and engaging /disengaging.

Mick and Fournier empirically illustrate that, in an attempt to reconcile the stresses and anxieties associated with these paradoxes, consumers adopt a range of behavioural coping strategies. Of particular interest here is the assertion that some technology paradoxes 
(control/chaos, freedom/enslavement, and new/obsolete) are more widely experienced and easier to articulate by consumers relative to others (particularly assimilation/isolation and engaging/disengaging). The inference here is that those individuals, such as disabled people, who use the Internet for shopping purposes, and who acutely experience the multiple facets of consumer vulnerability and exclusion in the physical marketplace, are more likely to encounter the latter paradoxes which they will actively seek to resolve as a means to strive towards normalcy.

TABLE 1:

EIGHT CENTRAL PARADOXES OF TECHNOLOGICAL PRODUCTS

\begin{tabular}{|c|c|}
\hline Paradox & Description \\
\hline Control/Chaos & $\begin{array}{l}\text { Technology can facilitate regulation or order, and technology can lead to } \\
\text { upheaval or disorder }\end{array}$ \\
\hline Freedom/enslavement & $\begin{array}{l}\text { Technology can facilitate independence or few restrictions, and technology } \\
\text { can lead to dependence or more restrictions }\end{array}$ \\
\hline New/obsolete & $\begin{array}{l}\text { New technologies provide the user with the most recently developed benefits } \\
\text { of scientific knowledge, and new technologies are already soon to be } \\
\text { outmoded as they reach the marketplace }\end{array}$ \\
\hline Competence/incompetence & $\begin{array}{l}\text { Technology can facilitate feelings of intelligence or efficacy, and technology } \\
\text { can lead to feelings of ignorance or ineptitude }\end{array}$ \\
\hline Efficiency/inefficiency & $\begin{array}{l}\text { Technology can facilitate less effort or time spent in certain activities, and } \\
\text { technology can lead to more effort or time in certain activities }\end{array}$ \\
\hline Fulfils/creates needs & $\begin{array}{l}\text { Technology can facilitate the fulfilment of needs or desires, and technology } \\
\text { can lead to the development or awareness of needs or desires previously } \\
\text { unrealized }\end{array}$ \\
\hline Assimilation/isolation & $\begin{array}{l}\text { Technology can facilitate human togetherness, and technology can lead to } \\
\text { human separation }\end{array}$ \\
\hline Engaging/disengaging & $\begin{array}{l}\text { Technology can facilitate involvement, flow, or activity, and technology can } \\
\text { lead to disconnection, disruption, or passivity }\end{array}$ \\
\hline
\end{tabular}

Source: Mick \& Fournier (1998, p. 126)

Indeed Mick and Fournier emphasise that the extent and saliency of technological paradoxes, as experienced by consumers, are mediated by a number of factors. These include the situation, type of product, the individual consumer involved, the coping strategies undertaken, as well as the amount and degree of conflict they experience arising from the consumption context. As such the coping strategies used by a consumer are likely to change, appear, disappear and reappear reflecting the nature of the paradox and context as it shifts and evolves over time. 


\section{"Danni" and "Rob" - An exploratory case study}

Given the complexities, multidimensional nature and context specifics of the concept of consumer vulnerability (Baker et al, 2005; Hunter-Jones, 2011), as well as the relative dearth of understanding of how disabled persons use the Internet for shopping purposes, the findings presented in this paper are inherently exploratory in nature. Adopting a theoretical sample (Guba \& Lincoln, 1989), these findings are based on data generated from a single ethnographic case study of "Danni", a wheelchair user (as a result of acute rheumatoid arthritis) and her husband, Rob. Whilst the limitations of such an approach are considered in the latter section of this paper, the decision to adopt this one particular case was based on the political nature of the phenomena of interest (Patton, 1980) as well as the need for an indepth, qualitative understanding to provide rich insights into substantive issues under investigation that could otherwise be lost (Geiger \& Prothero, 2007).

Danni and Rob, both in their late forties, lived in a terrace house in a social housing estate on the south coast of England with their two dogs and teenage son, David. ${ }^{1}$ Danni, a volunteer at the neighbourhood community centre, used a motorised mobility chair, her "buggy", to "shop locally" but also used the supermarket multiples' Internet shopping provisions either once or twice a month on average. ${ }^{2}$ Rob, a deputy store manager, was the sole earner of the household as well as the household's main mode of transport.

As with other sufferers of rheumatoid arthritis, a progressive condition characterised by the chronic inflammation of the joints that is, in most cases, unpredictable (Van Jaarsveld et al., 1998), Danni endured "flare-up" periods that alternated with times of remission during which she seemed, at least to some marginal extent, to recover (see also, for example, Evers et al.,

\footnotetext{
${ }^{1}$ To ensure confidentially, all names provided are pseudonyms

2 To respect the anonymity of the retailers discussed in this research, pseudonyms have been used
} 
1998). This was evident even on a weekly basis. Unlike research that has underscored the dynamics and fluidity of family/household structures even over short periods of time (Jackson et al., 2006; Mason \& Pavia, 2006) the composition of Danni and Rob's family remained relatively static throughout the study. As such this case provides us with an opportunity to explore the transient nature and evolving context of her use of the Internet as necessitated by her disability. Indeed, given the degenerative nature and the ferocity of her condition, Danni was severely limited in her physical and social activities, including her attempts to shop for groceries, an integral part of her role and responsibilities as a housewife (see, Doeglas et al., 1995). This had noticeable consequences on where and when she shopped both using stores and via the Internet.

\section{Methodology}

Although the ethnographic method is characteristically and instrumentally vague (Vidich \& Lyman, 2003), consistent with the logic of bricolage (Denzin and Lincoln, 2005), the data collection techniques used in this study are combined multiple complementary, consumer focussed methods (Elliott \& Jankell-Elliott, 2003). These included interviews, accompanied shopping trips, diaries, kitchen visits and photographs. In the spirit of grounded theory (Glaser \& Strauss, 1967), these methods were not predetermined from the outset of the study but rather were directed by the evolving nature of the phenomena under investigation and the demands of its context. The data collection was conducted over an eighteen month period and consisted of four main phases which will be discussed here in turn. As the self-identified main grocery shopper of her household, Danni was the primary focus of interest; however Rob also participated in the research but to a lesser extent. That is, Rob often drove Danni to the supermarket and shopped with her in-store. 
In accordance with the ethnographic objective of being as "experience-near" as possible (Geertz, 1973), the first phase of the study consisted of two extended interviews that were conducted with Danni at her home, each lasting between one and half and two hours. During these and subsequent interviews Danni was asked to describe her grocery shopping habits and practices both using stores and via the Internet. The emic goal of the interviews also meant that primacy was given to Danni's contribution to the interview (McCracken, 1988). Adopting this stance allowed Danni to voice her comments that guided the direction of the interviews while providing her with control of the content of what was being discussed (this was especially useful when discussing particularly sensitive and emotional issues). The issues raised in this phase of the research were continuously refined and subsequently built upon as the study progressed.

The second phase of the study involved accompanied shopping trips with Danni both in-store and online on the basis that shopping with consumers was a valuable research procedure for understanding consumers' shopping experiences in situ (Otnes, McGrath, \& Lowrey, 1995). This in turn offered a "rich experiential context" (Becker \& Geer, 1970) that aided the interpretation of Danni's discursive accounts of her shopping choices. During the accompanied at store shopping trip, Danni was asked to explain her choices as she shopped, which were recorded using an inconspicuous microphone suitable for the supermarket environment. After the event, both Danni and Rob were asked to reflect on their shopping experience (at the in-store café available on site). Using a similar design, on another occasion Danni was accompanied while she alone shopped online for groceries at home. This was again followed by a detailed discussion concerning her shopping experience. 
The third phase involved Danni completing a food shopping diary over a period of ten days in order capture a continual stream of data over a prolonged timeframe. Following a series of guidelines recommended in the literature (Corti, 1993), a semi-structured format was used, designed to capture both Danni's in-store and Internet shopping choices. Danni was provided with guidelines on how to complete the diary and was given examples, and was asked to write about her feelings, emotions, likes and dislikes during her shopping experience. The diary was not only useful for recording routines and Danni's everyday shopping practices (Meth, 2003) but also as a means for her to reflect on those practices. Following the structure of the food shopping diary, Danni was also asked to complete a further ten day diary at a later date specifically focussed on capturing her Internet usage. This diary was successful in documenting Danni's diverse and multi-faceted use of the Internet within her home and again served to encourage her to reflect on their online grocery shopping experiences and practices.

The final phase of data collection involved a further two extended at home interviews (including kitchen visits) with Danni that were timed around an online grocery shopping delivery. Building on the content of the empirical material that had been collected previously, a semi-structured format was used to provide Danni with a further opportunity to reflect on her grocery shopping choices as well as to discuss how her shopping habits and routines had changed over the eighteen month study period. This, in particular, allowed consideration of the transient and temporal nature of behavioural coping in a post-adoption context.

In preparation for the analysis phase of the study each of the interview tapes as well as the recordings of the accompanied shopping trips were transcribed verbatim. The individual transcripts were read and re-read several times as a means to become familiar with the data. As a matter of course, Danni and Rob (as and when applicable) were offered the opportunity 
to read their respective transcriptions although neither of them expressed a desire to do so. Starting with the first phase interview transcriptions, Spiggle's (1994) analytical framework was used to identify emerging thematic relationships (see also Thompson, 1997). Adhering to the logic of the "constant comparison" method (Goulding, 2005, p. 297), the same axial coding procedures were then systematically applied to the entries contained in the grocery shopping diary and, subsequently, the Internet usage diary to develop themes and categories as ascribed by Jones (2000). After considering rival interpretations, and refining provisional explanatory concepts, the transcriptions from the accompanied shopping trips and the final phase interviews were analysed. Given the ethnographic goal of "thick description" (Geertz, 1973), the empirical findings presented in this paper are organised around the inductive, datadriven a priori themes identified in the previous section of this paper that are illustrated with "archetypal episodes" from the study itself (Buttle, 1991).

\section{Findings}

This research explores the multiple and diverse strategies used by a disabled person to maintain and facilitate their independence (Kaufman, 1995; Bromley \& Matthews, 2007). During the first phase of the study, alongside shopping via the Internet, as a means to, in Danni's words, "reduce the onus on Rob" to drive her to and from the supermarket, she had increasingly come to use the smaller and independent stores in and around the neighbourhood for grocery shopping purposes. Danni was a self-proclaimed "community activist in the neighbourhood". This emerged to be rooted in her broader efforts to politicise the rights of the disabled community, especially since her own health began to decline. Danni's emphasised that "ignoring" smaller, particularly, independent stores also evoked a series of moral considerations (see Piacentini, Hibbert, \& Al-Dajani, 2001; Szmigin, Maddock, \& 
Carrigan, 2003) as such outlets were: "becoming increasingly scarce... but are the life-blood of every local community".

\section{Impracticalities of shopping: the inter-relationship between the ability to shop and actual vulnerability}

Despite these outlets being the most accessible to Danni, a recurrent theme that emerged related to the "impracticalities" of shopping using these retailers. As in Cahill and Eggleston's (1995) ethnographic study of wheelchair users' treatment in public spaces, such impracticalities appeared to be based on the dual considerations of Danni's own personal physical capabilities but also her concerns for others (see also, Kaufman \& Johnson, 2004). For example, the physical demands of carrying the items that she had bought back to the shopping basket that was attached to the front of her "buggy" made such shopping trips, in Danni's words: "limited". She also had to lock-up her motorised mobility chair, so "inquisitive children wouldn't be tempted to get in and hurt themselves", which was a "...time-consuming and often painful job in itself". Although the former was on occasion alleviated by a member of staff "doing the leg-work" on her behalf, e.g. aiding her with the shopping task (as evident in other studies, see Kaufman-Scarborough, 1999; 2001), Danni also talked about being limited in the amount and volume of products that she could shop for using these outlets. In particular, Danni explained that even if she could purchase more items from these retailers, such outlets did not tend to offer the range of products that she needed to meet all of her household's grocery shopping requirements (for similar examples, see Kirkup et al., 2004). This was largely as she perceived similar products offered by these outlets to be of a "poorer quality" and "relatively more expensive" compared to those available in the larger supermarkets and online. Interestingly, over and above these more practical measures, 
Danni emphasised that shopping via the Internet for groceries was "no easier" than shopping using stores:

Local shopping is much easier and more pleasant - but not always that practical. If there were more shops and a greater variety I would not have to use supermarkets. Internet shopping for food is no easier except for loading/unloading and going through the till. Because items are not always available, I sometimes can't cook something I wanted to - as I'm not able to make the substitution I want it annoys me... Local shopping is a bind because of the smaller variety of goods and they tend to cost more.

Indeed, the physical restraints imposed on Danni's personal mobility, combined with the increasingly frequent occasions that she could not "face" the car journey to and from the larger supermarkets (directly a consequence of the "excruciating" pain stemming from her illness) had principally led her to shop online for groceries.

If I'm not feeling particularly well - I mean when my arthritis is really badthe last thing I want to do is get into the car with Rob and go to Bestsupermarket or Supershop... I simply couldn't face the journey... At least with the Internet I always know that we have some food in.

As these remarks accentuate, owing to the unpredictability of her condition Danni was often faced with heightened degrees of uncertainty, threat and ambiguity when attempting to enact many of the facets of her everyday life, which by shopping online she had to some extent attempted to reduce and stabilise. This, in turn, despite Danni's reluctance to do so, led to the steady decrease of her use of local stores over the study period.

... it's a trade-off really... If Rob is tired when he gets in [from work] and I got some say rice in the cupboard and some chilli that can be defrosted... I'll do an online shop... If he isn't tired and we have nothing in.... we'll go to the supermarket if I know it isn't going to be busy or I'll send Rob to the shop if I'm really not feeling up to it.

In addition to the increasing physical constraints placed on Danni's ability to shop alone using the supermarkets in the area, during the latter stages of the study she also began to 
actively consider the times and days of the week when she and Rob shopped using these outlets. Such assessments were predominately based on her perceptions how "busy" these outlets were likely to be with other shoppers as a means to minimise stress and anxiety when shopping. In other words, an attempt to avoid the "crowd" (Shakespeare, 1998; Thomas, 2004), i.e. the sheer volume of traffic in-store that made navigating the store difficult as well as the process of shopping unduly demanding.

I might enjoy the shopping experience but on Saturday, well, I don't do stuff like that... so I don't join the crowds... we've got commitments... take David [her son] here and there... otherwise he might want to come [shopping] too we just don't do it or I'll just end up being really stressed and harassed.

A further constraint on Danni's store-based shopping behaviour and choices appeared to be her desire not to "stand-out in the crowd" (Stiker \& Sayers, 1999, p. 3) in her wheelchair. Indeed, beyond considerations of geographic accessibility, such concerns underpinned Danni's use of a particular supermarket rather than others in the area:

Wednesday: Went to Supershop. Didn't want to go, in a lot of pain. It was quiet and we got a disabled bay and trolley to fit the wheelchair easily. It was quite a pleasant shop, only a couple of people walking in front of us (the same people over and over(!))... I don't like it when that happens... it makes me (and them) feel a bit silly $: 2$

(Grocery shopping diary)

Furthermore, Danni also revealed that she considered the Supershop store to be "much easier... and less trouble" than shopping using their local Bestsupermarket superstore (that was situated a further two miles from her home). She and Rob also used this outlet largely because of the greater selection of non-food items that it offered. In particular this included electrical items and clothing, where she purchased David's school clothes, which made “shopping more interesting”, whereby emphasising the mundane nature of everyday food 
shopping (Miller et al., 1998). Danni also talked about having favoured the Supershop store over her local Discountsupermarket superstore, where she had purchased the majority of her household's grocery shopping before her arthritis became too severe, as in her words: "it was cheaper than any other supermarket... and offered good value for money”. However they had subsequently abrogated this particular store as it was "difficult to get around". Such comments highlight how price-related considerations attached to the use of some retailers can be comprised by a store's internal layout (Leszczyc, Sinha \& Timmermans, 2000), and how changes in personal mobility often led consumers to adapt their shopping behaviour and choices accordingly (see, Rhee \& Bell, 2002).

\section{Shopping 'properly': the inter-relationship between enacting normalcy and sense of self}

Concurrent with research that has emphasised that consumer choice and consumption decisions can be considered to be a political vote within the marketplace, and as a manifestation of consumer empowerment (Shaw, Newholm \& Dickinson, 2006), Danni and Rob appeared to avoid or reject using those retailers where ample access, sufficient parking and made available accommodative equipment (see similar findings in KaufmanScarborough, 1999) were not provided. Moreover, owing to Danni's arthritic pain, when retailers continually changed the layout of a store and the location of products, this made shopping more problematic as it required her and Rob to actively search for items which in turn led to longer periods of time spent in such outlets. Consequently this increased the likelihood of Danni feeling "annoyed and stressed" as well as instances where she was unable to "shop properly" (Jackson et al, 2006):

I don't like Discountsupermarket anymore.... I can't shop properly there.... It's laid out really differently than Bestsupermarket and Supershop and the aisles are in a different order... it's really hard to find anything.... hence why I don't often go there. The last time I did they'd changed it around again, it 
was really confusing.. ahrrr!... it took us too long to find everything.... it makes me feel a bit miserable sometimes.

Research that has focussed on social contexts of food consumption (e.g. Marshall \& Anderson, 2002) documents that responsibilities for meal preparation and cooking are often integral to a mother's sense of identity. When discussing shopping online for groceries, for example, Danni explained that as she planned ahead what meals she was to prepare a week or so in advance, as a tactical measure she often refused to accept products that had been substituted by the retailer as and when the specific products she "thought" she had bought were not available, as doing so would disrupt or, in her words, "make a mess of my plans". Such comments appeared to emphasise the centrality of forward planning and organising her family's meals (see, Ekström \& Jonsson, 2005) and how the successful execution of these tasks and activities continued to enable Danni to enact her motherhood role (Arnould \& Price, 2000). Indeed, Danni's ability to do her "thing [enact motherhood]" had become increasingly constrained as a direct result of her disability. It had become much less easy for her to "pop out to the shops" to purchase items that had been substituted by retailers.

Consequently the unavailability, or what Danni considered to be the "unsuitable substitution", of individual products and brands by retailers was a continual source of irritation and dissatisfaction when talking about shopping online for food. This was an issue, combined with her familiarity for shopping in-store with Supershop and Bestsupermarket, that led Danni to reject shopping online for particular grocery related items in favour of shopping in-store, as well as a consideration for not using alternative Internet shopping providers available in the area, that she had, in her words: "dabbled with" in the middle of the study period, notably Discountsupermarket.com:

God, Discountsupermarket [online] was terrible... I tried it a couple of times, but what they delivered was simply shocking.... I think chicken that had two 
days before it went out of date, same with sausages - and even eggs... We had a few days to eat everything... never again, they're rubbish.

Similarly during this time Danni revealed that she tended to purchase products that had been pre-loaded in her online shopping basket, items that she was convinced were likely to be available as they were very infrequently substituted by the retailer. This minimised her need to re-consider and reorganise her weekly meal plan; which could serve to disrupt her sense of coherence within the family (Holm, 2001) - or, in Danni words, “cause chaos". As Danni later discussed such items tended to include more staple and routine items, products that "it didn't really matter if [food was] substituted as long as something 'sensible' is offered as a replacement". This included perishable and less standardised goods.

I wouldn't buy fruit and veg from Bestsupermarket online full stop. Not even their pre-packaged and prepared stuff... I've never bought bread from them either or from Supershop online - tortilla wraps, yes, tinned goods, yes... dried foods, yes.... but they're the same no matter where you buy them.... and they last for a while in the cupboard...

As these comments highlight, Danni tended to use grocery retailers' Internet shopping provisions to shop for staple and more routine store cupboard items, as well as to actively search out products that were on offer or discounted. The latter mirrored that her search practices within store that had increasingly become constrained as a direct consequence of her disability, particularly when she experienced a "really bad flare-up". Consistent with Ratchford's (2001) notion of the accumulation of "human capital" in an online setting, the summation of this process of repetition, incremental learning and experience, appeared to reduce the time and energy when making such decisions online. This, in turn, enabled Danni to actively search out and compare both Supershop's website and Bestsupermarket.com (both shopping carts had been set-up with similar base products) to evaluate which of the two retailers had the best offers and discounted products. Such issues can be understood as an example of what Miller's (1998) calls "thrift" shopping, synchronised in both an online and 
store-based context, as well as symptomatic of Danni's attempts to, in her words - "shop 'properly'... like how I used to... but not so much that I become too dependent on the Internet”.

As evident in her Internet usage diary it was also apparent that when Danni shopped for other, non-grocery items online (the recurrent example being a digital camera) she appeared to spend a lot more time and energy searching out such items from a multiple of different retailers' website, including the supermarket multiples (de Kervenoael et al., 2006). This process involved comparing and contrasting the potential functions and features within a particular price bracket, using independent reviews and reports to lead to much more of an informed purchase decision and gained better "value for money". Although such issues are examined in detail in research focussing on satisfaction in an online setting (see, Anderson \& Srinivasan, 2003), Danni made it clear on several occasions that spending time shopping online for non-food items was difficult for her as a consequence of her disability:

...fine... it's great in fact... it's a lot different from [shopping for] food... because everyone does it... you know, food's different - it is for me anyway... I guess because sometimes I have to I guess... but it's a choice for other people.

Furthermore, akin to research that has examined the sophisticated mechanisms employed by physically disabled individuals to maintain their established, everyday routines (for a review, see Turner, 2001; Barnes \& Mercer, 2003), Danni also explained that the delivery of groceries to her home often took place during week days that were arranged between tasks that she was scheduled to conduct outside of the home. This included meetings at the local community centre or when waiting for either David or Rob to return home from school or work, respectively; events that she, in her words, was "increasingly unwilling to compromise". In other words, events that Danni had placed gradually more emphasis on over 
time in an attempt to "stay like it used to be"; particularly when her arthritis became more acute and thus restrictive of her own day to day activities as well as those of her family.

Moreover, during the final stages of the study, despite Danni's increasing attempts to persuade him to do otherwise, it emerged that Rob was unwilling to shop for online groceries:

We shop together - but Danni does the Internet shop... I wouldn't know where to start really, anyway she does it much better than I could, and I don't really want to get involved... I wouldn't have thought she would trust me doing it... Danni knows what she is doing...

(Rob - Interview transcript)

Previous studies have examined the interactions between the sufferer of rheumatoid arthritis and their spouse and have emphasised that their experiences are not always supportive (e.g. Martire et al., 2002). However, it was evident earlier in the study that when Rob shopped together with Danni in-store this appeared not only to be a pragmatic decision but also, more fundamentally, a means to reinforce their relationship through this mundane act of provisioning. For example, although when shopping in-store Danni's product and brand decisions appeared to be determined by price related concerns, where she tended not to deviate from her pre-prepared shopping list, on one marked occasion she attempted to justify the expense of purchasing a new brand of air-freshener to Rob. Rob subsequently dismissed as this idea as "a silly buy", nevertheless Danni ignored him and placed the item in their shopping trolley before moving on to another aisle.

Rob: put it down!

Danni: why?

Rob: it's nearly two pounds that's why. Come on if we need air-freshener what about this one [points to a less expensive brand]. Look it's Glade

Danni: I'm getting this one... it's a new one, I've seen it advertised on the TV ... and smell [sprays a small amount of the contents of the can in the direction of Rob] - it smells really nice and it's quite strong... It'll cover the smell of David's trainers in the hall and your work shoes [both laugh]. 
Rob: fine.. but I don't think there's any need for it. This one would do perfectly well.

As the above excerpt demonstrates, Rob's involvement in the shopping process appeared to yield much deeper beneficial outcomes rather than those based purely practical considerations. Indeed such an example can be interpreted as a moment of intimacy between Danni and Rob; an illustration of what Miller (1998) refers to as "making love in supermarkets" whilst compensating, to some extent, for Danni's disability and their attempts to strive towards normalcy.

\section{Discussion}

This paper sought an understanding of how the multiple facets of consumer vulnerability and exclusion intersect with the Internet as a shopping provision. In particular this study explored the store-based and Internet grocery shopping experiences by considering and contextualising the everyday encounters of a disabled person - Danni - and the implications her actual vulnerability had for her sense of self, her ability to shop and normalcy (see Baker et al, 2005). Figure 1 depicts states of being and the influences on and implications of each condition. That is, actual vulnerability is reinforced as a consequence of the impracticalities of shopping; significantly affecting normalcy and the ability to shop properly. Subsequently this leads to exclusion, isolation and stigma (even if this is only temporal) influencing sense of self and the ability to belong. Utilising a grounded theory approach, this figure was developed from an emerging interpretation of the empirical data and consideration of a priori themes identified in the extant literature and is central to our understanding of the interrelated concepts associated with vulnerability and shopping. Danni's use of her wheelchair in supermarkets which were busy with able-bodied shoppers and/or poorly laid out led to feelings of stigma. Although it has been suggested that the feeling of empowerment 
engendered by shopping properly would be alleviated by shopping online (Social Exclusion Unit, 2005) this was not evident here. In addition to Danni's actual vulnerability (e.g. severe physical pain) and the temporal influence of her condition she was required to develop strategies to facilitate her ability to shop.

The study reported here provides novel and rich insights into actual consumer vulnerability and the behavioural coping mechanisms adopted by Danni that empowered her with the ability to enact the consumption practices central to the construction and reinforcement of her sense of self (Mick \& Fournier, 1998; Baker et al, 2006).

FIGURE 1:

CONSUMER VULNERABILITY AND SHOPPING: INTERRELATED CONCEPTS 


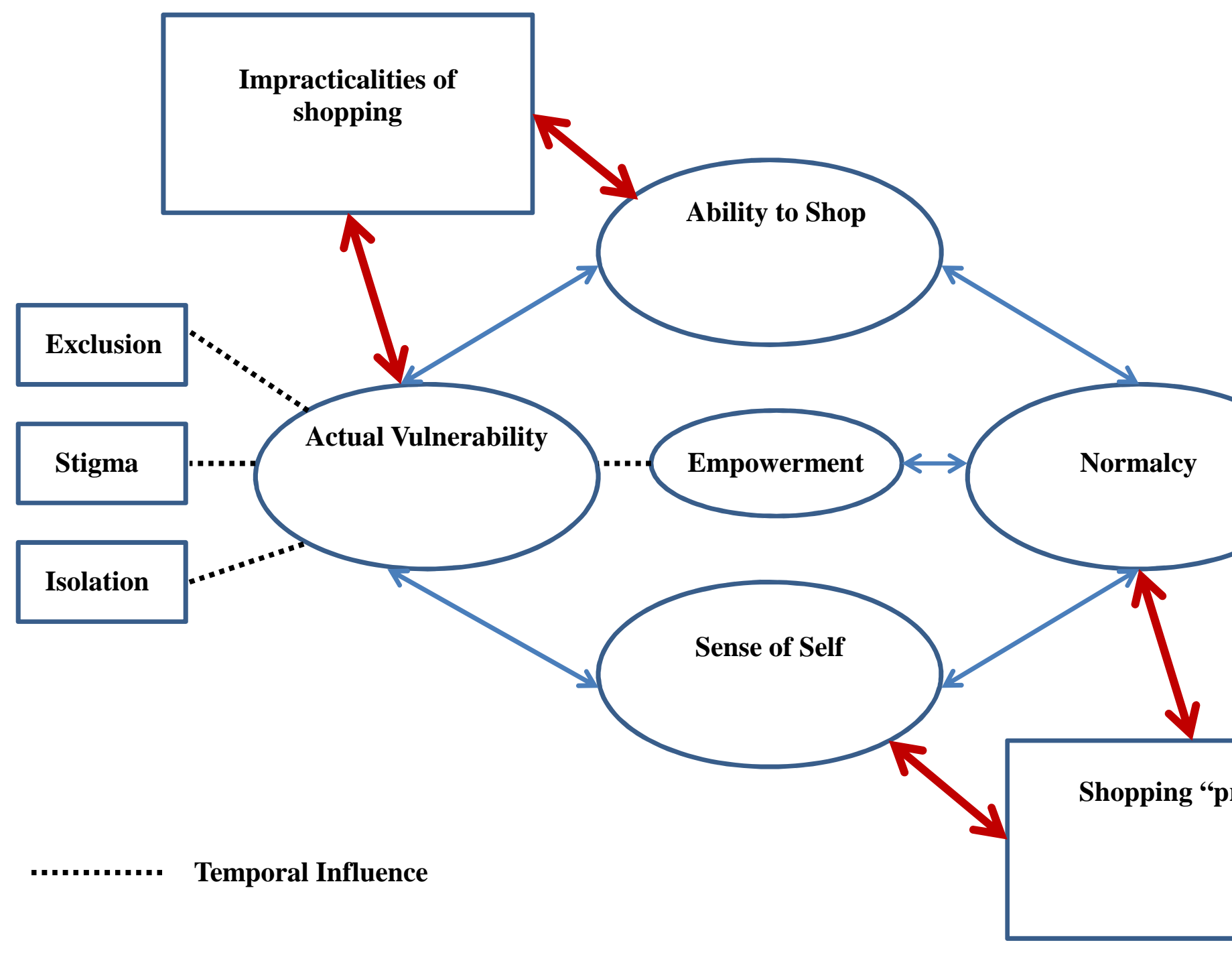

It has been suggested that a disabled person's identity instability and loss of normalcy is likely to be exacerbated and perpetuated by both changes in individual as well as household and domestic circumstances, such as grief, divorce, unemployment, amongst other things (Gentry et al, 1995). It was evident that in Danni's case when her disability increased as her condition worsened and/or during periods when her illness "flared up" that she felt excluded and unable to shop "properly". At these times she was able to rely on the use of the Internet to ensure access to grocery provisions. However, as people shop in-store to relieve feelings of isolation (Baker, 2006) it was obvious that during these physical restraints on Danni's personal mobility that she felt excluded. Similarly, being unable to shop using stores at 
particular times (e.g. weekends) to avoid the stigma she feels in crowds as a consequence of her wheelchair was further evidence of the interrelationship between the impracticalities of shopping and actual vulnerability.

Shopping has also been identified as a form of therapy to help re-assemble sense of self (Gentry et al, 1995) and by Baker (2006) as a way in which consumers can continue with their roles. These claims are supported here as Danni has identified the significance of her role as a wife and mother in the family (see Valentine, 1999; Kan \& Gershuny, 2010) and the way in which being able to shop "properly" facilitates this. Although strategies have to be employed by Danni to manage grocery shopping (see below) it is evident that she views shopping as one of her key roles (as does her husband) and that this also allows her to be an active agent in her own decision making (Baker, 2006). Shopping in-store for Danni, because she is accompanied by her husband Rob, also helps maintain their emotional relationship (see Miller, 1998). This engenders both belonging and inclusion for Danni and as such is pivotal to understanding the experiences of vulnerable consumers. Whilst Childers and KaufmanScarborough (2009, p. 577) suggest that "convenience may have additional meanings for consumers with disabilities that need to be examined and understood" it is clear here that shopping is emotionally laden and that although the use of the Internet for grocery shopping may be perceived as more convenient there are many other motivations to take into account when shopping which will also be influenced by transient and temporal dynamics.

\section{Limitations and suggestions for further research}

As underscored earlier in this paper, this study is inherently exploratory in nature and therefore limited in its scope. However, the use of a single ethnographic case has enabled us to reveal and unravel not only the strategies employed by Danni to manage her disability and 
the barriers she continues to overcome in order to provide the necessary grocery provisions for her family but, more than this, offered an opportunity to generate an insight into the reality of shopping practices by a vulnerable consumer. Given the period of study and the multiplicity of methods employed here the rich data has afforded a genuine impression of the lived experience of Danni and has highlighted a number of significant ways in which shopping provision, both on and off line, has the potential to be enhanced to ensure social inclusion requirements are met.

Studies have previously explored consumers' identity projects during such "liminal" states (Turner, 1969), when consumers are "betwixt and between" (Gentry et al., 1995, p. 68) particular social roles and/or life stages (see, for example, Banister and Piacentini, 2008; Hogg, Piacentini and Hibbert, 2009). These changes evoke consumers to employ a series of coping strategies to "buffer" (Schouten, 1991) and ease themselves through periods of transition and flux. Mick and Fournier (1998) assert that some behavioural coping strategies for managing technology paradoxes are more widely experienced and easier to articulate by some consumers relative to others. The data here illustrates that managing the paradoxes of assimilation/isolation and engagement/disengagement are of particular relevance in the case of vulnerable consumers. However, further research in this area would be appropriate to explore these issues to a greater extent.

Specifically, although there are occasions where Danni uses the Internet for grocery shopping for convenience, generally she experiences isolation and frustration as the system does not necessarily adequately provide for her emotional and social needs. To manage the paradox of assimilation/isolation she will rely on her spouse to engage in her shopping experiences with her to be included in a society designed for able-bodiedness. Further to this, although she 
prefers not to engage with the practice of using the Internet for grocery shopping, there are specific aspects with which she disengages, for example not buying perishable items such as fresh fruit and vegetables. This allows her to engage with shopping "properly" but shops for fewer items as some produce can be bought via the Internet. This therefore reduces the effort she associates with shopping using stores whilst benefitting from the normalcy afforded to her when she does so. These findings also begin to respond to the call for further research from Kaufman-Scarborough and Childers (2009) which suggests examining the online expertise among people with disabilities. Danni is very familiar with price comparison sites for example and readily able to garner information she needs regarding grocery and nongrocery items.

As previously identified, Danni's husband Rob is keen to reinforce Danni's role as wife and mother through her organising and provisioning of food for the family and this includes Danni's "expertise" when buying food online. It may be that Rob too is (consciously or otherwise) facilitating Danni's coping strategies by disengaging with online provision as a means of underpinning her capability. The role of the partner or spouse in the consumption experiences of vulnerable consumers needs further research. Additionally, further research that involves a more diverse group of vulnerable consumers at different life stages, for example, would allow vulnerability to be understood in a wider context by listening to and observing their experiences (Baker et al, 2005). The role of those not considered as the "main shopper" but nevertheless influential in decision making could be developed in future research studies.

\section{Implications}


It would appear that rather than the Internet being of benefit to those who are limited in their store-based choices there are actually a number of issues associated with using online grocery retail provision. That is, there are complexities associated with the types of grocery items that can be reliably purchased online. For example, when providers made "substitutions" to Danni's order she was forced to reconsider her forward planning for her family meals. To overcome the frustration of being sent inappropriate items and through a process of elimination, Danni had identified the groceries that were less likely to be "replaced" and purchased them as a matter of course when they were pre-loaded in her online basket. The notion then that the Internet as a grocery shopping provision is a simple solution for the vulnerable consumer is evidenced here as unfounded.

Shopping in-store for groceries also meant employing multiple strategies to minimise physical discomfort as well taking into account the wider context of the overall shopping experience; that is at times that ensured minimal customer traffic so that Danni's personal mobility would be less limited meant thoughtful forward planning. The unavailability and misuse of provisions provided by the supermarkets to give less mobile shoppers access to the store also impacted on the choices Danni made. She rejected stores in the area that did not provide adapted shopping carts or "visible" members of staff to help when required. The constant re-organising of store layout (a managerial strategy designed to encourage consumers to spend longer in-store - Goss, 1993) was a source of irritation and discomfort for Danni who liked to minimise her shopping time as she was often in pain. The "simple" alternative of ordering these groceries online to avoid such situations was not always an option as, already outlined above the system did not necessarily meet all of Danni's shopping requirements. 
If the disabled are not to be "locked out" of store-based provision, and where social exclusion as a consequence of being less able-bodied has to be overcome, this study has been important on a number of levels. Firstly the detail provided in respect of day-to-day shopping practices over an eighteen month period illustrates the importance of generating an understanding of the lived experience. Although policies designed to enhance social inclusion can be viewed positively, recognising the reality as opposed to the rhetoric of such approaches can facilitate development and improvements in the system. The design of the research has also ensured the "voice" of Danni is heard and through these archetypal episodes a clear understanding of the reality of managerial decision making has been established.

Secondly, the perception of online provision specifically with reference to fresh produce has implications for retailers. Particularly when brands have been built on the values of quality and freshness there are clearly risks associated with delivering items that are considered to be sub or below expected standard. Whilst it is recognised that retailers are operating a business, and that using food near its sell-by date in home deliveries may be managerially astute, the longer term implications of brand perception, particularly in relation to word of mouth, cannot be underestimated (Corstjens \& Corstjens, 1995).

Finally, where vulnerable consumers want (or have) to access to physical stores this paper has also highlighted a number of ways in which the service for consumers like Danni can be improved. The social stigma associated with using a wheel chair can be minimised by adequate car parking provision and store personnel on hand and willing to engage with these less able-bodied consumers. Investment in a greater number of adapted shopping aids could also facilitate the shopping experience. These changes appear relatively straightforward and whilst they may impact on the "bottom line" the extent to which retailers are genuinely engaging with the social inclusion agenda could be measured in the ways outlined above. 


\section{References}

Amtmann, D., \& Johnson, K. (1998). The Internet and information technologies and consumer empowerment. Technology and Disability, 8(3), 107-113. doi: 10.1016/S10554181(98)00026-0

Anderson, R., \& Srinivasan, S. (2003). E-satisfaction and e-loyalty: A contingency framework. Psychology and Marketing, 20(2), 123-38. doi: 10.1002/mar.10063

Arnould, E. \& Price, L. (2000). Authenticating acts and authoritative performances: questing for self and community. In S. Ratneshwar, D. Mick and C. Huffman, The Why of Consumption (pp. 140-63), New York: Routledge.

Baker, S. \& Kaufman-Scarborough, C. (2001). Marketing and public accommodation: a retrospective on Title III of the Americans with Disabilities Act. Journal of Public Policy \& Marketing, 20(2), 297-304. doi:10.1509/jppm.20.2.297.17370

Baker, S. (2006), Consumer normalcy: Understanding the value of shopping through narratives of consumers with visual impairments, Journal of Retailing, 82(1), 37-50. doi: 10.1016/j..jretail.2005.11.003

Baker, S., Gentry., \& Rittenburg, T. (2005). Building understanding of the domain of consumer vulnerability, Journal of Macromarketing, 25(2), 128-139.

doi:10.1177/0276146705280622

Banister, E. \& Piacentini, M. (2008). Drunk and (dis)orderely: The role of alcohol in supporting liminality. Advances in Consumer Research 35, 311-18. Retrieved at:

http://www.acrwebsite.org/volumes/v35/naacr_vol35_209.pdf

Barnes, C., \& Mercer, G. (2003). Disability, London: Polity Press.

Becker, H., \& Geer, B. (1970). Participant observation and interviewing: a comparison. In W. Filstead (Eds.), Qualitative Methodology: Firsthand Involvement with the Social World (pp. 133-142). Chicago, IL: Markham Publishing Company.

Bromley, R., \& Matthews, D. (2007). Reducing consumer disadvantage: reassessing access in the retail environment. International Review of Retail, Distribution and Consumer Research, 17(5), 483-501. doi: 10.1080/09593960701631904

Bromley, R., \& Thomas, C. (1993). The retail revolution, the carless shopper and disadvantaged. Transactions of the Institute of British Geographers, 18, 222-236.

Buttle, F. (1991), What people do with advertising. International Journal of Advertising, 10, 95-110.

Cahill, S., \& Eggleston, R. (1995). Reconsidering the stigma of physical disability: wheelchair use and public kindness. Sociological Quarterly, 36(4), 681-698.

Childers, T., \& Kaufman-Scarborough, C. (2009), Expanding opportunities for online shopping with disabilities, Journal of Business Research, 62, 572-578.

doi:10.1016/j.jbusres.2008.06.01

Clarke, I., Hallsworth, A., Jackson, P., de Kervenoael, R., Perez Del Aguila, R., \& Kirkup, M. (2004). Retail competition and consumer choice: contextualising the "food deserts" debate. International Journal of Retail and Distribution Management. 32(2), 89-99. doi: http://dx.doi.org/10.1108/09590550410521761

Commuri, S., \& Ekici, A. (2008). An enlargement of the notion of consumer vulnerability, Journal of Macromarketing, 28 (2), 183-186. doi:10.1177/0276146708316049

Corti, L. (1993). Using diaries in social research. Social Research Update, 2, 1-4.

Davies, R., \& Champion, A. (1980). Social Inequality in Shopping Opportunities: How the Private Sector Can Respond. Cheshnut: Tesco Stores.

Davis, L. (1995). Enforcing Normalcy: Disability, Deafness, and the Body. London: Verso. 
De Kervenoael, R., Soopramanien, D., Elms, J., \& Hallsworth, A. (2006). Exploring value through integrated services solutions: the case of e-grocery shopping. Managing Service Quality, 16(2), 185-202. doi: 10.1108/09604520610650646

Denzin, N. and Lincoln, Y. (Eds.). (2005). Handbook of Qualitative Research. London: Sage. Doeglas, D., Surrmeijer, T., Krol, B., Sanderman, R., Van Leeuwen, M., \& Van Rijswijk, M. (1995). Work disability in early rheumatoid arthritis. Annals of the Rheumatic Diseases, 54, 455-460. doi: 10.1136/ard.54.6.455

Ekström, M., \& Jonsson, I. (2005), Family meals: competence, cooking and company. Department of Home Economics Working Paper, Goteborg University Sweden. Retrieved from www.mv.helsinki.fi/home/palojoki/english/nordplus/FAMILY_MEALSpipping.pdf Elliott, R., \& Jankel-Elliott, N. (2003). Using ethnography in strategic consumer research. Qualitative Market Research: An International Journal, 6(4), 215-223. doi: 10.1108/13522750310495300

Evers, A., Kraaimaat, F., Geenen, R., \& Bijsma, J. (1998). Psychosocial predictors of functional change in recently diagnosed rheumatoid arthritis patients. Behaviour Research and Therapy, 36(2), 179-193. doi: 10.1016/S0005-7967(98)00019-9

Fitch, D. (2002). Digital inclusion, social exclusion and retailing: an analysis of data from the 1999 Scottish Household Survey. Technology and Society, 1, 309-313. doi:

10.1109/ISTAS.2002.1013831

Geertz, C. (1973). The Interpretation of Cultures. New York, NY: Basic Books.

Geiger, S. \& Prothero, A. (2007). Rhetoric versus reality: exploring consumer empowerment in a maternity setting. Consumption, Markets \& Culture, 10(4), 375-400. doi: $10.1080 / 10253860701566218$

Gentry, J. Kennedy, P. Paul, C. \& Hill, R. (1995). Family transitions during grief:

Discontinuities in household consumption patterns. Journal of Business Research, 34(1), 67 79. doi: 10.1016/0148-2963(94)00054-I

Glaser, B., \& Strauss, A. (1967). The Discovery of Grounded Theory: Strategies for Qualitative Research. Chicago, IL: Aldine.

Goss, J. (1993). "The "magic of the mall": an analysis of form, function, and meaning in the contemporary retail built environment. Annals of the Association of American Geographers, 83(1), 18-47. doi: 10.1111/j.1467-8306.1993.tb01921.x

Goulding, C. (2005). Grounded theory, ethnography and phenomenology: a comparative analysis of three qualitative strategies for marketing research. European Journal of Marketing, 39(3/4), 294-308. doi: 10.1108/0309056051058178

Guba, E. \& Lincoln, Y. (1989). Fourth Generation Evaluation. Newbury Park, CA: Sage. Guy, C. (2007). Planning for Retail Development: A Critical View of the British Experience. London: Routledge.

Hand, C., Dall'Olmo Riley, F., Harris, P., Singh, J., \& Rettie, R. (2009). Online grocery shopping: the influnce of situational factors. European Journal of Marketing, 43(9/10), 12051219. doi: 10. 1108/03090560910976447

Hebl, M., Tickle, J., \& Heatherton, T. (2000). Awkward moments in interaction between nonstigmatized and stigmatized individuals. In T. Heatherton, R. Kleck, M. Hebl and J. Hull (Eds.), The Social Psychology of Stigma (pp. 275-306). New York, NY: Guilford Press. Hevey, D. (1993). From self-love to the picket line: strategies for change in disability representation. Disability and Society, 8(4), 423-9. doi: 10.1080/02674649366780391 Hill, R., \& Dhanda, K. (1999), Gender inequity and quality of life: a macromarketing perspective, Journal of Macromarketing, 19(2), 140-152. doi:10.1177/0276146799192005 Hill, R., \& Dickinson, R. (2005). In this special issue on vulnerable consumers. Journal of Macromarketing, 25(2), 127. doi:10.1177/027614670502500201 
Hogg, M. Piacentini, M. \& Hibbert, S. (2009). The role of symbolic consumption in identity projects: the case of fostered children. Advances in Consumer Research 36, 613-15.

Retrieved at: http://www.acrwebsite.org/volumes/eacr/vol8/eacr_vol8_149.pdf

Holm, L. (2001). Family Meals. In U. Kjaernes (Ed.), Eating Patterns: A Day in the Lives of Nordic Peoples. Lysaker: National Institute for Consumer Research.

Hunter-Jones, P. (2011). Consumer vulnerability and exclusion: A study of carers in the tourism marketplace. Journal of Marketing Management, 27(1-2), pp. 165-180.

doi: 10.1080/02672571003737809

Imrie, R. (1996). Disability and the City. London: Sage.

Jackson, P. \& Holbrook, B. (1995). Multiple meanings: shopping and the cultural politics of identity. Environment and Planning A, 27(12), 1913-30. doi: 10.1068/a271913

Jackson, P., Perez del Aguila, R., Clarke, I., Hallsworth, A., de Kervenoael, R., \& Kirkup, M. (2006), Retail competition and consumer choice 2: understanding consumer choice at the household level, Environment and Planning A, 38, 47-67. doi: 10.1068/a37208

Jones, K. (2000). The unsolicited diary as a qualitative research tool for advanced research capacity in the field of health and illness. Qualitative Health Research, 10, 555-567. doi: $10.1177 / 104973200129118543$

Jordan, B. (1996). A Theory of Poverty and Social Exclusion. Cambridge: Polity Press.

Kan, M. \& Gershuny, J. (2010), Gender segregation in domestic labour: evidence from longitudinal time-use data. In J. Scott., R. Crompton, and C. Lyonette, Gender Inequalities in the $21^{\text {st }}$ Century. (pp. 138-162). Cheltenham, Glos: Edward Elgar.

Kaufman, C. (1995). Shop 'til you drop: tales from a physically challenged shopper. Journal of Consumer Marketing, 12(3), 39-55. doi: 10.1108/07363769510090455

Kaufman, J., \& Johnson, C. (2004). Stigmatized individuals and the process of identity. Sociological Quarterly, 45(4), 807-833. doi: 10.1111/j.1533-8525.2004.tb02315 Kaufman-Scarborough, C. (1999). Reasonable access for mobility-disabled persons is more than widening the door, Journal of Retailing, 75(4), 479-508. doi: 10.1016/S00224359(99)00020-2

Kaufman-Scarborough, C. (2001). Sharing the experience of mobility-disabled consumers. Journal of Contemporary Ethnography, 30(4), 430-464. doi: 10.1177/089124101030004004 Kaufman-Scarborough, C., and Childers, T. (2009), Understanding markets as online public places: from consumers with visual impairments, Journal of Public Policy \& Marketing, 28(1), 16-28. doi: 10.1509/jppm.28.1.16

Kirkup, M., de Kervenoael, R., Hallsworth, A., Clarke, I., Jackson, P., \& Perez-del-Aguila, R. (2004). Inequalities in consumer choice: exploring consumer experiences in suburban neighbourhoods. International Journal of Retail and Distribution Management, 32, 511-522. doi: 10.1108/09590550410564746

Kitchen, R. (1998). "Out of place", "knowing one's place": space, power, and the exclusion of disabled people. Disability and Society, 13(3), 343-356. doi: 10.1080/09687599826678

Leszczyc, P., Sinha, A., \& Timmermans, H. (2000). Consumer store choice dynamics: an analysis of the competitive market structure of grocery stores. Journal of Retailing, 76(3), 323-345. doi: 10.1016/S0022-4359(00)00033-6

Lupton, D., \& Seymour, W. (2000). Technology, selfhood and physical disability. Social Science and Medicine, 50(12), 1851-1862. doi: 10.1016/S0277-9536(99)00422-0

Marshall, D., \& Anderson, A. (2002). Proper meals in transition: young married couples on the nature of eating together. Appetite, 39(3), 193-206. doi: 10.1006/appe.2002.0507 Martire, L. Druley, J. Stephens, M. \& Wojno, W. (2002). Negative reactions to received spousal care: predictors and consequences of miscarried support. Health Psychology, 21(2), 167-76. doi: 10.1037/0278-6133.21.2.167 
Mason, M., \& Pavia, T. (2006). When the family system includes disability: Adaptation in the marketplace, roles and identity, Journal of Marketing Management, 22, 1009-1030. doi: 10.1362/026725706778935637

Matthews, M. \& Vujakovic, P. (1995). Private worlds and public places: Mapping the environmental values of wheelchair users. Environment and Planning A, 27(7), 1069-83. doi: 10.1068/a271069

McCracken, G. (1988). The Long Interview. Newbury Park, CA: Sage.

Meth, P. (2003). Entries and omissions: using solicited diaries in geographical research. Area, 35(2), 195-205. doi: 10.1111/1475-4762.00263

Mick, D. (2008). Introduction: The moment and place for a special issue. Journal of Consumer Research, 35, 377-379. doi: 10.1086/591482

Mick, D., \& Fournier, S. (1998). Paradoxes of technology: consumer cognizance, emotions, and coping strategies. Journal of Consumer Research, 25 (September), 123-143. doi: $10.1086 / 209531$

Miller, D. (1998), A Theory of Shopping, Cambridge: Polity Press

Miller, D., Jackson, P., Thrift, N., Holbrook, B., \& Rowlands, M. (1998). Shopping, Place and Identity. London: Routledge.

Milligan, C. (1998). Pathways of dependence: the impact of health and social care restructuring - the voluntary experience. Social Science and Medicine, 46(6), 743-53. doi: 10.1016/S0277-9536(97)00172-X

Moisio, R. Arnould, E. \& Price, L. (2004). Between mothers and markets: constructing family identity through homemade food. Journal of Consumer Culture, 4(3), 361-84. doi:10.1177/1469540504046523

Office for Disability Issues (2010), General Demographics, Retrieved at:

http://www.officefordisability.gov.uk/disability-statistics-and-research/disability-facts-andfigures.php\#gd

Otnes, C., McGrath, M., \& Lowrey, T. (1995). Shopping with consumers usage as past, present and future research technique. Journal of Retailing and Consumer Services, 2(2), 97110. doi: 10.1016/0969-6989(95)00025-9

Patton, M. (1980). Qualitative Evaluation Methods. Beverley Hills, CA: Sage.

Piacentini, M., Hibbert, S., \& Al-Dajani, H. (2001). Diversity in deprivation: exploring the grocery shopping behaviour of disadvantaged consumers. International Review of Retail, Distribution and Consumer Research, 11(2), 141-158. doi: 10.1080/09593960122639 Piachuad, D., \& Webb, J. (1996). The Price of Food: Missing Out on Mass Consumption. London: STICERD, LSE.

Ratchford, B. (2001). The economics of consumer knowledge. Journal of Consumer Research, 27(4), 397-411. doi: 10.1086/319617

Rhee, H., \& Bell, D. (2002). The inter-store mobility of supermarket shoppers. Journal of Retailing, 78(4), 225-237. doi: 10.1016/S0022-4359(02)00099-4

Rogers, E. (1995). Diffusion of Innovations $\left(4^{\text {th }}\right.$ ed). New York, NY: The Free Press.

Schouten, J. (1991). Selves in transition: symbolic consumption in personal rites of passage and identity reconstruction. Journal of Consumer Research, 17(4), 412-25.

Shakespeare, T. (Ed.). (1998). The Disability Reader: Social Science Perspectives. London: Continuum.

Shaw, D., Newholm, T., \& Dickinson, R. (2006). Consumption as voting: an exploration of consumer empowerment. European Journal of Marketing, 40(9/10), 1049-1067. doi:

$10.1108 / 03090560610681005$

Social Exclusion Unit (2005). Inclusion Through Innovation: Tackling Social Exclusion

Through New Technologies. Retrived from

www.socialexclusion.gov.uk/downloaddoc.asp?id=768 
Spiggle, S. (1994). Analysis and interpretation of qualitative data in consumer research. Journal of Consumer Research, 21(3), 491-503.

Stiker, H., \& Sayer, W. (1999). A History of Disability. Michigan, MI: University of Michigan.

Szmigin, I., Maddock, S., \& Carrigan, M. (2003). Conceptualising community consumption: farmers' markets and the older consumer. British Food Journal, 105(8), 542-550. doi: 10.1108/00070700310497291

Tempelman, S. (1999). Constructions of cultural identity: multiculturalism and exclusion. Political Studies, 47(1), 17-31. doi: 10.1111/1467-9248.00185

Thomas, C. (2004). How is disability understood? An examination of sociological approaches. Disability and Society, 19(6), 569-583. doi: 10.1080/0968759042000252506 Thompson, C. (1997). Interpreting consumers: a hermeneutic framework for deriving marketing insights from the texts of consumers' consumption stories. Journal of Marketing Research, 34, 438-455.

Tiley, C., Bruce, C., \& Hallam, G. (2007). Adaptive technology for people with disabilities using information and communication technologies. In D. Jones (Ed.), Improving Library Services to People with Disabilities (pp. 65-88). London: Chandos Publishing.

Turner, B. (2001). Disability and the Sociology of the Body. London: Sage.

Turner, V. (1969), The Ritual Process: Structure and Anti-Structure, New York, NY: Aldine. Valentine, G. (1999). Eating in: home, consumption and identity. The Sociological Review, 47(3), 491-524. doi: 10.1111/1467-954X.00182

Vidich, A., \& Lyman, S. (2003). Qualitative methods: their history in sociology and anthropology. In N. Denzin and Y. Lincoln (Eds.), The Landscape of Qualitative Research (pp. 55-130). Thousand Oaks, CA: Sage.

Wendell, S. (1989). Toward a feminist theory of disability. Hypatia, 4(2), 104-128. doi: 10.1111/j.1527-2001.1989.tb00576.x

Westlake, T. (1993). The disadvantaged consumer: problems and policies. In R. Bromley and C. Thomas (Eds.), Retail Change: Contemporary Issues. London: UCL Press. Whelan, A., Wrigley, N., Warm, D., \& Cannings, E. (2002). Life in a "food desert". Urban Studies, 39, 2081-2100. doi: 10.1080/0042098022000011371

Williams, P., \& Hubbard, P. (2001). Who is disadvantaged? Retail change and social exclusion. International Review of Retail, Distribution and Consumer Research, 11, 267286. doi: 10.1080/713770599 